\title{
RECONSTRUCTION OF MARRIAGE ZONATION IN ISLAMIC LAW PERSPECTIVE
}

\author{
Syariful Alam \\ Faculty of Law, University of Muhammadiyah Malang \\ Jl. Raya Tlogomas No. 246, Malang, East Java, Indonesia \\ E-mail: syarifulalam@umm.ac.id
}

\begin{abstract}
Zoning, a limitation system that is so widely discussed today, focuses initially on the education system in Indonesia, namely on the problem of admission of new students which began in 2017. One of these policy settings is for children to be educated in areas close to residence. This system is often connected by the public with the search for a partner to get married. Based on normative Islamic law research, marriage in Islam does not provide specific restrictions regarding this zoning in finding a partner. However, this zoning can be implicit in the recommendations of marriage in Islam. Bringing up conflict that has become a topic of discussion in many media and communities, which in the end, can create a solution for couples who find it difficult to find a life partner as well as presenting internal conflicts that pertain to the realm of privacy, intersect with the right of humans to freely choose from and where their partners. Regardless of a marriage that leads to the coercion of one partner or coincidence of finding the right partner according to the zoning where the couple lives.
\end{abstract}

Keywords: Marriage Zonation; Education System; Islamic Law; Couples; Conflict

\section{A. INTRODUCTION}

The Ministry of Education and Culture of the Republic of Indonesia has implemented the Zoning System since 2017 on the admission of new students, regulated in Article 15-17 of Minister of Education and Culture No. 17 of 2017. One background of this policy is that children be sent to school in areas close to where they live. Thus reducing transportation costs and traffic congestion. Also, eliminated favorite or favorite school label. Even high-quality students do not accumulate in certain schools.

Considered burdensome for new students, this system also receives criticism from prospective students and various groups of parents. Crowded was discussed both in print and electronic media, the zoning system was viral in the community. This system is also often linked by the community with various existing things, be it teacher zoning, work zoning until zoning in the search for a partner to get married. 
The essence of marriage is to unite two people, namely men and women in one legal bond to foster the household. Marriage is a commitment in which there is an emotional bond between two people to share between psychological and biological responsibilities. The marriage that occurs is based on a sense of love and affection that is lived together and side by side between husband and wife. ${ }^{1}$ Marriage is formalized through a marriage event, a married couple who are officially married ideally choose to live together under one roof, the same area, and spend time together. For most people, a marriage relationship is seen as a very relationship intimate and is a relationship that lasts longer when compared with all existing close relationships.

As God's creatures who are equipped with a love for other types, humans are also biological beings who have the desire and intention to develop offspring with the aim of preserving human beings. However, besides its function as a successor generation, it is also expected to become a straightforward generation (shalih generation) who will be able to bring people to makrufan and prevent people from being disobedient. To regulate all that, Islam provides the media as a facilitator in the form of marriage. ${ }^{2}$ Every married couple wants a family form that is harmonious and in accordance with their dreams. The realization of harmony in the family that affects love for each married couple and their children, not only because of love alone. But there are other factors that need to be considered and become obstacles to forming a harmonious family, which is harmony. Although in the beginning the husband and wife loved each other and wanted to form a family in accordance with the dream of the husband and wife. There is no harmony ${ }^{3}$ and there are too many differences between them and can not be overcome anymore then the marriage can not proceed as desired and often end in divorce.

Marriage arranged by parents and tradition is not always approved by the perpetrators, the individual wishes to choose his own partner, this has long been present as expressed by Geertz in Abangan, Santri, Priyayi ${ }^{4}$ but at that time his presence was considered as a disturbance in the middle of a tradition that had been there being. The development of the era facilitates the entry of various new cultures that have an influence on systems and structures in people's lives, including traditions related to marriage. Research at the University of Chicago in the American Journal of Sociology, related to changes in marital patterns, says that the influence of the mass media brings contact with new ideas and examples of foreign behavior originating from Western Europe and the United States with their tendency to choose their own partners. Research on the purpose of marriage among young people in

\footnotetext{
${ }^{1}$ Halford, K., Marriage and Relationship Education, Guilford Press, New York, NY: 2011, p. 78.

${ }^{2}$ Marhumah, Membina Keluarga Mawaddah Warahmah dalam Bingkai Sunnah Nabi, PSW IAIN Sunan Kalijaga, Yogyakarta: 2003, p. 98.

${ }^{3}$ Euis Nurlaelawati, For the Sake of Protecting Religion: Apostasy and its Judicial Impact on Muslim's Marital Life in Indonesia, Journal of Indonesian Islam, Vol. 10, no. 1, 2016, pp. 89-112

${ }^{4}$ Clifford Geertz, Abangan, Santri, Priyayi dalam Masyarakat Jawa. PT. Midas Surya Grafindo, Jakarta: 1989, p. 112.
} 
Malaysia ${ }^{5}$ found individual motifs such as mutual love, friendship, happiness, hope, personal beliefs, life culture and individual life in various individual motives for marriage. These findings confirm that marriages arranged by parents through arranged marriages are experiencing a decline in prevalence, and customarily marriages are made on the basis of individual choice itself at this time Thomas F. O'Dea revealed that religion has been characterized as unifying the most sublime human aspirations, as a large amount of morality, the source of social order and individual inner peace, as something that makes humans civilized. ${ }^{6}$ History even shows that religious institutions are the most likely form of human association to survive.

This study uses normative juridical research methods that are qualitative in nature. A normative juridical study or study of legal norms is a study that refers to legal norms contained in legislation and norms that live and grow in society. The qualitative research is a study that analyzes legal norms in-depth and holistically or comprehensively.

The existence of Islamic law, in this case, can be an alternative solution to solve problems that develop in specific societies in the issue of marriage zoning. Islamic law has now been assimilated and can become one of the references to renew the rule of law that is no longer able to accommodate the behavior of people who tend toward badness. Based on the description above, the focus of this paper is on how Islamic law provides solutions to legal problems related to marriage zoning that is developing in Indonesia today.

\section{B. RESULT AND DISCUSSION}

\section{Definition of Zoning and Marriage}

It is necessary to know in advance what is meant by the zoning itself, in the Indonesian Big Dictionary (KBBI) records the meaning of the word zoning associated with the division of territory, namely the division of the territory of all cities which are classified based on their designation or condition and potential. In another meaning is division or splitting of an area into several sections, according to the function and purpose of management. ${ }^{7}$

By referring to the meaning of zoning "in accordance with the function and purpose of management", it is possible that the use of this zoning phrase contains a broader meaning not only related to geography.

Humans as social beings certainly can not meet their needs physically and mentally without the contribution of others. From this, we need cooperation and harmonious

${ }^{5}$ T. D. Raphalalani and N. M. Musehane. Arranged Marriage Practices of the Vhavenda Community of the Vhembe District, Limpopo Province, South Africa. vol. 4 no. 2 (2013), pp. 18-22.

6 Thomas F. O’Dea, Sosiologi Agama. CV. Rajawali, Jakarta: 1990, p. 67.

${ }^{7}$ KBBI, https:kbbi.web.id/zonasi, accessed: 25 July 2019. 
interaction. But over time, the closer the relationship the more demands and the easier it is to maintain it. Included in matters of marriage. ${ }^{8}$

The true understanding of marriage, in general, is an engagement between two individuals who give birth to official kinship through marriage ceremonies in social life. Marriage in Islam ${ }^{9}$ has its basis, goals, conditions, and harmony. In marriage, there are four things that become the task of marriage for a husband and wife to be able to maintain family intimacy and harmony, namely (1) division of responsibilities in domestic life, (2) communication, (3) sex in marriage, and (4) acceptance of changes that occur to the couple all the time in marital life. ${ }^{10}$

In Islam, marriage is known as the collected and united. According to other terms, it can also mean Ijab Qobul (marriage contract) which requires communication between a pair of people spoken by words intended to proceed to marriage, according to regulations required by Islam. Furthermore, it is used with the word zawaj, used in the Koran to mean a couple who in their use can also be interpreted as marriage, Allah make humans pair up with each other, justify marriage and forbid adultery.

In terminology, marriage is a contract that allows for sexual intercourse and having fun using the recitation of inkah or tazwij pronunciation, and this is an essential part of the contract. $^{11}$

Marriage is a common sunnatullah and applies to all of His creatures, both humans, animals, and plants. This is the method chosen by Allah, as a way for His creatures to multiply, and preserve their lives. The notion of marriage is literally interpreted as sexual relations. In other words, marriage is nothing more than sexual relations. ${ }^{12}$ This literal meaning then experiences an expansion of meaning, and the expansion of this meaning is then agreed upon as the definition of marriage referred to by the Koran, namely the covenant ('aqd) seriously carried out by a man and woman in the context of the validity of a relationship sexual. Studies show that the quality of a good marriage is characterized by good communication, intimacy, and closeness, sexuality, honesty, and trust. All these factors are very important to establish a satisfying marriage relationship. ${ }^{13}$

Another better definition of marriage is found in Marriage Law No. 1 of 1974 chapter 1. There it is stated: "marriage is a spiritual bond between a man and a woman as husband and

\footnotetext{
${ }^{8}$ M. Quraish Shihab, Pengantin al-Qur'an. Lentera Hati, Tangerang: 2007,, p. 103.

${ }^{9}$ Sohari Sahrani T., Fikih Munakahat Kajian Fikih Nikah Lengkap, PT Raja Grafindo Persada, Serang: 2008, p. 90.

${ }^{10}$ D. Elfida, Penyesuaian Perkawinan Ditinjau dari Beberapa Faktor Demografi, Jurnal Psikologi, Vol. 7, no. 2 (2011), pp. $190-214$.

11 'Abd al-'Aziz Al-Malyabari Z., Fath al-Mu'in Bi Syarhi Qurrah al-'Ain, III, Daar al-Fikr, Beirut: p. 567.

12 A. Mustari, Reinterpretasi Konsep-konsep Hukum Pernikahan Islam, I. Alauddin University Press, Samata: 2011, p. 88

13 I. Niswati, "Hubungan Loving, Kepuasan Seksual, dan Religiusitas dengan Keharmonisan Perkawinan”. Jurnal Psibernetika, vol. 4, no. 2 (2011), pp. 1-32.
} 
wife with the aim of forming a happy and eternal family (household) based on the Godhead of the One". ${ }^{14}$

There are also those who interpret marriage in terms of language means contract, gathering, and intercourse. Meanwhile according to terms, ${ }^{15}$ marriage is a contract that contains legal relations between men and women, obligated to help and determine the rights and obligations of each as a husband and wife.

Meanwhile, the harmony is to go through a marriage contract to become a husband and wife. The implementation will involve: (1) Prospective husband and wife (2) Guardian as aqid (who married off) (3) Mahar (4) Marriage contract (5) Witness.

Thus the purpose and wisdom of marriage are as follows: a) Getting closer to Allah SWT, b) Distributing biological needs, c) Continuing offspring, c) Withstanding immorality, d) Eliminating everyday needs, e) To get peace of life (mawaddah wa rahmah), f) Implement sharia requirements, g) Create cooperation and responsibility, h) Strengthen silaturrahim.

Before marriage, known in the term khitbah in Islam. The word "khitbah", in Arabic terms has the same root word as al-khithab and al-khathab. The word al-khathab means "conversation". When said takhathaba means "two people who are talking". If it is said khathabahu fi amr it means "he is discussing something with someone". If the khitbah (talk) is related to the issue of women, then the meaning that is first captured is a conversation related to the issue of marriage. ${ }^{16}$ Thus that the khitbah means a discussion relating to the proposal or request for marriage. There are two conditions in khitbah, namely the conditions Mustahsinah and Lazimah.

Requirements mustahsinah is a condition in the form of advice to a man who will propose a woman to research the woman who will be married first, so as to ensure the survival of the household later. This mustahsinah requirement is not a requirement that must be fulfilled before the proposal is made, but only in the form of good advice and habits. Without these conditions fulfilled, the proposal remains valid. As for the requirements of mustahsinah are as follows: ${ }^{17}$

a. The woman who is to be married should be as matched as the man who asked for her marriage, as in her position in society, ${ }^{18}$ both in form, in the same level of wealth, in knowledge and so on.

b. Women who are to be married should be women who have compassion and women who are not infertile, because of these qualities will determine the tranquility in domestic life,

\footnotetext{
${ }^{14}$ S. Mulyati, Relasi Suami Istri dalam Islam. PSW UIN Syarif Hidayatullah, Jakarta: 2004, p. 34.

${ }^{15}$ Ratno Lukito, The Enigma of Legal Pluralism in Indonesian Islam: The Case of Interfaith Marriage, Journal of Islamic Law and Culture, vol. 10, no. 2, 2008, pp. 179-91

${ }^{16}$ C. Takariawan, Izinkan Aku Meminangmu. (Solo: Era Intermedia, 2004), p. 33.

${ }^{17}$ K. Muchtar, Asas-asas Hukum Islam Tentang Perkawinan, (Jakarta: Bulan Bintang, 1974), p. 109.

18 Parolin, Gianluca P., "Interfaith Marriages and Muslim Communities in Scotland: A Hybrid Legal Solution?", Electronic Journal of Islamic and Middle Eastern Law (EJIMEL), vol. 3, no. 17, 2015, pp. 83-96
} 
especially when in the midst of their presence children will surely add to the happiness and prosperity of domestic life.

c. The woman who is to be married should be a woman who is far from blood relations with the men who ask for her hand. Religion prohibits a man from marrying a woman who is very close in blood relations.

d. Knowing the physical condition, behavior, and so on of the women to be married.

e. Know the identity of the prospective spouse comprehensively, regarding work, education, descent, family, and more importantly the quality of character and religion. ${ }^{19}$

f. It is preferred that the wife to be married is still a girl (not a widow). ${ }^{20}$ Because girls, in general, are still fresh and have never been in love with another man.

Whereas the Lazimah provisions are conditions that must be met before a marriage request is made. An application for a legal marriage depends on the conditions of the lazimah. Which includes the conditions of Lazimah are: ${ }^{21}$ a. The woman to be married is not in a marriage agreement with another person. $b$. The woman to be married is a woman who has no husband and is not in an iddah state, allowed, either openly or innuendo. c. The woman being married is not the mahram of the proposing man.

\section{Marriage Zoning Exposition}

Related to zoning or territoriality in marriage can refer to the order in the community that exists today, which is a pattern or marriage system in the community order called "Endogamy" and "Exogamy".

Endogamy marriage is a marriage between someone from within their own group, the group in question is in the form of an ethnic group. Marriage with this system usually aims to preserve ethnicity or territory, for example, Javanese married to Javanese. Bugis people with Bugis people. This form of marriage is permissible in Islam as long as it does not include women who are forbidden to be married. ${ }^{22}$

Endogamy marriage is also a system that requires marriage with a spouse of the same tribe or descendant with it or forbids someone to marry someone from another ethnicity or family. There are also those who argue that endogamous marriages give birth to offspring by intermarriage between individuals in a very close kinship group. Endogamy is very diverse depending on the culture in the place. For example endogamy in the form of caste, religious endogamy, tribal endogamy or descent. According to Hazan \& Shaver, ${ }^{23}$ attachment is an emotional bond that is intertwined with a sticky figure that is formed since the early days of an individual's life and continues into his adult life in order to fulfill a sense of security. The

\footnotetext{
${ }^{19}$ R. Hakim, Hukum Perkawinan Islam. (Bandung: Pustaka Setia, 2000), p. 76.

${ }^{20}$ K. Thalib, Perkawinan Menurut Islam, (Surabaya: al-Ikhlas, 1993), p. 134

${ }^{21}$ K. Muchtar, Asas-asas Hukum Islam Tentang Perkawinan, (Jakarta: Bulan Bintang, 1974), p. 21.

22 A. Mustari, Reinterpretasi Konsep-konsep Hukum Pernikahan Islam, I, (Samata: Alauddin University Press, 2011), p. 75

${ }^{23}$ Hazan, C., \& Shaver, P. R., "Romantic Love Conceptualized As An Attachment Process", Journal of Personality and Social Psychology, vol. 52, no. 3 (1987), pp. 511-524.
} 
type of attachment in adulthood is divided into three types namely secure attachment type, avoidance attachment type, and anxious attachment type. The quality of an individual's marriage with his partner will be determined by these three types of attachment. ${ }^{24}$ Other research also explains that individuals with a secure attachment type generally have high marital satisfaction compared to individuals with an insecure attachment type that is anxiety and avoidance. ${ }^{25}$

Whereas exogamy marriages are marriages between ethnicities, clans, tribes, kinship in different environments. Eksogami can be divided into two types, viz:

a. Connubium asymmetric exogamy occurs when two or more neighborhoods act as a giver or recipient of a girl as in the Batak and Ambon marriage.

b. Connubium symmetric exogamy if in two or more environments it is exchanging soul mates for young people.

Exogamy covers heterogamy and homogamy. Heterogamy is a marriage between different social classes such as noble children married to peasant children. Homogamy is a marriage between classes of the same social group as the example of a merchant's son/merchant who marries a merchant's/merchant's child.

In the marriage system in South Sulawesi and West Sulawesi it is applied that marriage must be understood as a form of marriage based on customary rules and customs that apply in the local community. ${ }^{26}$ These rules are cultural manifestation which consists of values and norms. Those values and norms are reflected as cultural heritage so that they can provide strength in interacting with people's behavior patterns.

As described above, that the bride and groom before marriage or can be said to be at the matchmaking stage, must heed the suggestions in asking to marry the prospective wife, both mustahsinah and lazimah requirements. However, the system that lives in the marriage community must be understood as a form of marriage based on customary rules and customs that apply in the local community. So, customs in the confusion of this community can be one factor in marriage, especially if it is related to the Endogamy and Eksogamy family system so that it can provide insight into the zoning of marriage in the community. ${ }^{27}$ This issue will be reviewed that how the view of Islamic law in providing consequences.

${ }^{24}$ C. S. Hollist, \& Miller, R. B., "Perceptions of Attachment Style And Marital Quality in Midlife Marriage. Family Relations", vol. 54, no. 1 (2005), pp. 46-57

${ }^{25}$ R. Banse, "Adult Attachment and Marital Satisfaction: Evidence Dyadic Configurations Effects", Journal of Social and Personal Relationships, vol. 21, no. 2 (2004), pp. 273-282.

${ }^{26}$ A. K. Ahmad MS, Sistem Pernikahan di Sulawesi Selatan dan Sulawesi Barat, I, (Makasar: INDOBIS Publishing Anggota IKAPI, 2006), p. 211.

${ }^{27}$ W. M. Novenanty, “ANTARA PEKERJA DALAM SATU PERUSAHAAN,” vol. 2, no. 1 (2015), pp. $60-85$. 
This writing will focus on endogamy and exogamy marriage zoning which is then reviewed with the perspective of Islamic law, especially marriage zoning based on the candidate's environment whether tribal, customs, place or genealogy or nasab.

\section{Endogamy Marriage in Islamic Perspective}

As explained earlier, endogamous marriage is a system that requires marriage with a spouse of the same tribe or descendant with it or prohibits a person from entering into a marriage with someone of another ethnicity or ethnicity. There are also those who argue that endogamous marriages are marriages by means of marriage between individuals in a very close kinship group. Endogamy is very diverse depending on the cultures in the place. For example endogamy in the form of caste, religious endogamy, tribal/offspring endogamy.

Islam is pure teaching, in the sense that its guidance is always in line with the conditions of human life, judging that marriage is a natural way of life, ${ }^{28}$ marriage is fundamental in the formation of an Islamic family, the prophet Muhammad PBUH praised the behavior as part of his sunnah.

The purpose of marriage is to realize the family sakinah (peace), mawaddah (mutual respect) and rahmah (love each other). ${ }^{29}$ This can be done by aligning the three namely the essence of human spirituality, motivation and goals that will be achieved in marriage.

Marriage is a clean and instinctive feeling that must be fulfilled in the corridors of the Shari'a and the religion of God. Marriage between close relatives (endogamy) can weaken the stimulation of husband and wife, which sometimes makes a cold relationship between the two. Especially if the husband and wife used to grow together under one roof. Also, marriages between close relatives can lead to hereditary diseases.

Several studies have found that there is a relationship between the quality of marriage and childcare environment. The quality of the caregiving environment is affected one of which is the quality of marriage. ${ }^{30}$ While the quality of marriage of husband and wife and the quality of the family environment are factors that will determine the behavior of children. ${ }^{31}$ Furthermore, the quality of the caregiving environment is also influenced by the quality of marriage, the wife's education, and family size. ${ }^{32}$ Even the interaction between father and son

${ }^{28}$ E. Marriages, "Marriage Quality and Family Well-Being Determine Parental Environment of," vol. 10, no. 1 (2017), pp. 1-12

${ }^{29}$ A. Syahraeni, Bimbingan Keluarga Sakinah, (Makasar: Alauddin Press, 2013), p. 115

30 T. Herawati, "Manajemen Sumberdaya Keluarga dan Ketahanan Keluarga Peserta Program Pemberdayaan Masyarakat di Pedesaan (Kasus di Kabupaten Bogor) (Disertasi), (Institut Pertanian Bogor, Bogor, Indonesia, 2012), p. 244.

31 Rizkillah R., Sunarti, E., Herawati T., "Kualitas Perkawinan dan Lingkungan Pengasuhan Pada Keluarga Dengan Suami Istri Bekerja”, Jurnal Ilmu Keluaga dan Konsumen, vol. 8, no. 1 (2015), pp. 10-19

32 C. S. Lai, "Parental Marital Quality and Family Environment as Predictor of Delinquency Amongs Selected Secondary School Students in Malaysia", British Journal of Arts and Social Sciences, vol. 2, no. 2 (2011), pp. 102-121. 
will have a positive effect on the quality of marriage. ${ }^{33}$ While one of the factors that influence the quality of marriage of husband and wife is the characteristics of children and social support. $^{34}$

Marriage between relatives has a positive side, in addition to the negative side. The choice to hold marriage between relatives is left entirely to the consideration of the two prospective husbands and wife, coupled with expert doctor's advice. And for the better, the families of a Muslim is not closed in matters of marriage. A family should connect the marriage rope with another person's family that is not of one descendant so that the fabric of social and community relationships is getting stronger. According to Laurenceu et al, ${ }^{35}$ selfdisclosure is one of the characteristics that describe intimacy, because a relationship cannot be said to be intimate if the couple closes each other by not providing personal or confidential information.

Rasulullah Muhammad PBUH. give advice to anyone who wants to get married to choose his future wife carefully, because offspring greatly affect the nature and behavior of a person. There is guidance in Islam that forbids marrying women because of religious factors such as mother, daughter, sister, father's aunt, mother's aunt, daughter's sister, ${ }^{36}$ this is in accordance with the word of Allah in the Quran surah an-Nisa / 4: $23::^{37}$

Forbidden unto you are your mothers, and your daughters, and your sisters, and your father's sisters, and your mother's sisters, and your brother's daughters and your sister's daughters, and your foster-mothers, and your foster-sisters, and your mothers-in-law, and your step-daughters who are under your protection (born) of your women unto whom ye have gone in - but if ye have not gone in unto them, then it is no sin for you (to marry their daughters) - and the wives of your sons who (spring) from your own loins. And (it is forbidden unto you) that ye should have two sisters together, except what hath already happened (of that nature) in the past. Lo! Allah is ever Forgiving, Merciful.

The purpose of the mother here is the mother, grandmother and so on and what is meant by girls is daughters, grandchildren and so on and so on, as well as others. while what is meant by your wife's children who are in your care, according to the majority of scholars, including stepchildren who are not in their care.

${ }^{33}$ Puspitawati, H., \& Setioningsih, S. S., "Fungsi Pengasuhan dan Interaksi Dalam Keluarga Terhadap Kualitas Perkawinan dan Kondisi Anak Pada Keluarga Tenaga Kerja Wanita (TKW)", Jurnal Ilmu Keluarga dan Konsumen, vol. 4, no. 1 (2011), pp. 11-20.

${ }^{34}$ Kersh, J., Hedvat, T. T., Hauser-Cram, P., \& Warfleld, M. E., "The Contribution of Marital Quality to The Well-being of Parents of Children With Developmental Disabilities", Journal of Intellectual Disability Research, vol. 50, no. 12 (2006), pp. 883-893.

${ }^{35}$ R. Miller, \& Perlman, D., Intimate Relationship (5th ed.), (New York: McGraw-Hill, 2009), p. 233.

${ }^{36}$ Z. Al-Najjar, Al-'Ijaz al-'Ilmi fi al-Sunnah al-Nabawiyah, terj. Zidni Ilham Faylasufa, Sans dalam Hadis, (Jakarta: Amzah, 2011), p. 26.

37 "Ayat Al-Quran, https://ayatalquran.net/2015/01/surah-an-nisaa-the-women-terjemah-bahasainggris/, 23 July 2019 
So it is clear that in Islam there is zoning or jurisdiction where marriage is not permissible, namely regarding nasab. Islam forbids a future husband to marry a woman who is not his mahram. ${ }^{38}$ If to avoid violating nasab zoning, let the prospective husband and wife check all that is related to the offspring and character of each potential marriage partner.

\section{Exogamy Marriage in Islamic Perspective}

As mentioned earlier, exogamy is a marriage between ethnic, clan, tribe, kinship in different environments. This marriage grows with the assumption that humans live in groups or groups to defend their lives. So there is no reason at all to reject their union in marriage. ${ }^{39}$ Intercultural marriages (inter-ethnic marriages) are marriages that occur between couples who come from different cultural backgrounds. ${ }^{40}$ Culture becomes an important aspect of marriage, where couples naturally have in terms of cultural values that are adhered to, according to their beliefs and habits, as well as cultural and lifestyle habits. In marriage, two different cultures, different backgrounds, different tribes are united. These different backgrounds can cause a mismatch. This mismatch can cause conflict, both about habits, dominant behavior, and family interference.

Exogamy covers heterogamy and homogamy. Heterogamy is a marriage between different social classes such as noble children married to peasant children. Homogamy is a marriage between classes of the same social class as an example of a merchant's child or a merchant who is married to a merchant's child or trader too.

Thus it is clear that exogami has a broad scope, namely: ethnic differences (ethnic groups, sub-tribes), different villages or different villages, different religions, different castes, different classes, and social status.

If viewed from the form of cousin marriage, it is only divided into two, one of which is 'Cross Causin' matrilineal. A woman will leave her group and move to her husband's group, but she will continue to bear her own family. ${ }^{41}$ 'Cross Cousin' is a form of marriage of children of siblings of different sexes. This type of marriage is still very well known in the community. This marriage was carried out due to various considerations between the two families. One reason is that kinship relations remain well established. But the impact of this marriage is also very influential in the family. If there is a problem in a very principle marriage, then the relationship between the two families can be disrupted. And the potential for division between families. Parallel Cousin is a form of marriage of children of siblings of the same sex. ${ }^{42}$

${ }^{38}$ Alex Minichele Sewenet, Fasil Merawi Tessagaye, and Getnet Tadele, "Interreligious Marriage: Social and Religious Perspectives”, Imperial Journal of Interdisciplinary Research, vol. 3, no. 6 (2017), pp. 233-250

${ }^{39}$ Roger M Keesing, Antropologi Budaya, (Jakarta: Penerbit Erlangga ,1981), p. 18.

${ }^{40}$ Mia Retno Prabowo, "Penyesuaian Perkawinan Pada Pasangan Yang Berlatar Belakang Etnis Batak Dan Etnis Jawa”, Skripsi Universitas Gunadarma, Fakultas Psikologi, (Jakarta, 2010), p. 7.

${ }^{41}$ Helga Septiani Manik, "Makna dan Fungsi Tradisi Sinamot dalam Adat Perkawinan Sukubangsa Batak Toba di Perantauan Surabaya", Vol. I, No. I (2012), pp. 19-32.

${ }^{42}$ Roger M. Keesing, Antropologi Budaya, (Jakarta: Penerbit Erlangga, 1981), p. 5. 
In Indonesia, the term Exogami is more familiar with the term 'Mixed Marriage'. Marriage policy in Indonesia, namely Constitution No.1 of 1974 concerning marriage has governed mixed marriages and only focuses on mixed because of differences in citizenship. Mixed marriages are permitted and if conducted overseas, then after returning to Indonesia immediately register proof of marriage to the Marriage Registration Office where they live.

In the social environment in the family system in Indonesia, mixed marriages have become a specific group's mores in Indonesia. The following are some examples of mixed marriages in Indonesia: a) Mixed marriages of different nationalities in Singkawang, West Kalimantan, are known as export marriages to Taiwan countries. Some people in Singkawang consider their only hope to escape poverty by 'exporting' their daughters. b) Different caste mixed marriages in Bali, women with higher castes must discourage them from marrying men of the lower caste. This is in contrast to higher caste men. Men can marry any caste. Meanwhile, if a woman continues to marry, then she is banished from her family and her caste, with a Pattiwangi ceremony.

Mixed marriages of different classes and social status, as well as mixed marriages, are different in some areas. With the improvement of education, several social classes that used to be below, with education have been able to taste equal education, and have the potential to increase political and economic resources. In Toro, Central Sulawesi, women are not allowed to marry men of different classes. If this happens, then pay mokalabu (pay replacement) ${ }^{43}$ in the form of a white buffalo with a traditional ceremony in the community by traditional elders.

Inter-ethnic mixed marriages in this paper are marriages between men and women who come from different tribes or different sub-tribes or villages or villages. In Padang, West Sumatra, marriages must be carried out between tribes, because one tribe is still considered blood. However, with the Guci tribe, which is also one of the sub-tribes in Padang, it is permissible, because the Guci tribe is considered a combination or fraction of the existing tribes.

In the view of Islam itself, the classification of ethnicity (ethnicity, sub-ethnicity), village or village, caste, different classes, and social status actually does not exist, such differences as those born from adat and the environment in the community.

However, Islam recommends a number of suggestions that intersect with the various classifications of a mixed marriage (exogamy) above. As with the previous endogamy discussion, there are a number of suggestions for carrying out marriage requests from an Islamic perspective.

\section{Equality (Kafa'ah) As A Marriage Zoning Solution}

${ }^{43}$ M. Ali, "Muslim Diversity: Islam and Local Tradition in Java and Sulawesi, Indonesia," Indones. J. Islam Muslim Soc., vol. 1, no. 1 (2011), pp. 7-20 
Furthermore, in Islam, there is the term kafa'ah (equality). Kafa'ah comes from the Arabic from the word Sفى, means equal or equivalent. ${ }^{44}$ In the term fiqh, $k a f a ' a h$ is called as a partner, meaning that it is the same, similar, balanced, or harmonious. ${ }^{45} \mathrm{Kafa}$ 'ah or kufu ', according to language means equal, balanced, or harmonious, or conformity, similar, equivalent or comparable. ${ }^{46}$ According to the term, Islamic law which is meant by kafaah or $k u f u^{\prime}$ in marriage is balance and harmony between the prospective wife and husband so that each candidate does not find it difficult to get married. ${ }^{47}$

Kafa'ah in Islamic law terminology is a requirement that a Muslim husband must be equal, the same level or higher than his wife, even though a woman can choose her partner in marriage. This aims to prevent him from marrying men who are below the level. ${ }^{48}$ The problem of kafa'ah that needs to be considered and measured is a straight and polite attitude of life not because of heredity, occupation, wealth, and so on. A pious man of the even lower bloodline has the right to marry a high-ranking woman. Men who are respected for their position and wealth have the right to marry women of high rank and fame. Likewise, even a poor man, entitled and permitted to marry a rich woman, as long as he is a Muslim and can distance himself from begging and no guardian hinders or demands cancellation.

In another perception, what is meant by kafa'ah or kufu' in marriage according to the provisions of Islamic law, namely the balance and harmony between the prospective wife and prospective husband so that each candidate does not feel hard to carry out the marriage. Or a man who is equal to his future wife, equal to his position, equal in social level and equal in character and wealth. ${ }^{49}$ So, the pressure in kafa'ah is balance, compatibility, and harmony. One part of an individual's personality that plays a role in determining the quality of an individual's relationship with a partner is the attachment. ${ }^{50}$

So kafa'ah here can be interpreted as harmony so that the two couples feel equal and do not harm each other. Balance and harmony between the prospective wife and husband so that each candidate does not find it difficult to get married. ${ }^{51}$ Or a man equal to his future wife, equal in position, equal in social level and degrees in character and wealth. In a study conducted found that couples who have the same interests, do something together, and have friends with the same game, feel more satisfied in the relationship compared to couples who

${ }^{44}$ A. Syarifuddin, Hukum Perkawinan Islam di Indonesia, Antara Fiqh Munakahat dan Undang-Undang Perkawinan, III, (Jakarta: Kencana, 2009), p. 78.

${ }^{45}$ K. Muchtar, Asas-asas Hukum Islam Tentang Perkawinan, (Jakarta: Bulan Bintang, 1974), p. 45.

${ }^{46}$ M. A. Mujib dkk, Kamus Istilah Fikih, (Jakarta: Pustaka Firdaus, 1995), p. 28.

${ }^{47}$ A. R. Ghozali, Fiqh Munakahat, (Jakarta: Pustaka Firdaus, 2008), p. 96.

${ }^{48}$ Mona Siddiqui, Menyikap Tabir Perempuan Islam, (Bandung: Nuansa, 2007), p. 83.

${ }^{49}$ Sohari Sahrani, Fikih Munakahat Kajian Fikih Nikah Lengkap, (Serang: PT Raja Grafindo Persada, 2008), p. 17

${ }^{50}$ Collins, N. L, \& Read, S. J., "Adult Attachment, Working Models, and Relationship Quality in Dating Couples”, Journal of Personality and Social Psychology, vol. 58, no. 4 (1990), pp. 644-663.

${ }^{51}$ R. Nurviani and R. Ilham, "Efektivitas Pelatihan Empati dalam Mengurangi Konflik Perkawinan pada Pasangan Suami Istri yang Berada pada Tahun Awal Pernikahan”, vol. 3, no. 2 (2018), pp. 165-176. 
are less active together. ${ }^{52}$ The couple's personality and partner's living conditions in terms of the level of intimacy and communication can be said to be the source that most often causes satisfaction or dissatisfaction in a relationship. Personality characteristics will influence the way couples accept each other, assess and explain events that occur in marriage. ${ }^{53}$

Harmony in this kafa'ah differs from caste or level in mixed marriages which has been discussed a bit above. In fact, the recommendation to get married outside the territorial and social zoning in the view of Islamic law is in the form of a recommendation that is essentially aimed at extending friendship and avoiding marriage from the kinship nasab zone by still criminalizing kafa'ah (harmony).

\section{CONCLUSION}

Marriage zoning in the perspective of Islamic law is more focused on the scope of hereditary zoning which can occur through kinship marriages with limited scope or can be called endogamy. To avoid all this, Islamic law provides a perspective through the recommendations contained in conditions relating to marriage zoning, namely those who want a better marriage life, then beforehand must know the identity of the prospective life companion comprehensively, regarding work, education, family), family, and more importantly, the quality of character and religion.

Furthermore, for women who are going to get married, it must be a woman who is far from blood relations with the man who asks to marry her or there is no kinship of one lineage. Islam forbids a man from marrying a woman who is very close in blood relations because there are more dangers and deficiencies that result in poor quality and health, both physical and mental offspring subsequently. Besides that harmony or kafa'ah also becomes important as a marital zoning limit in terms of values and self-esteem and dignity of each family. Maintain social inequalities that might occur in the midst of living a married life.

\section{REFERENCES}

A. Mujib, M., dkk, Kamus Istilah Fikih, Pustaka Firdaus, Jakarta: 1995.

Al-Malyabari, 'Abd. al-'Aziz, Fath al-Mu'in Bi Syarhi Qurrah al-'Ain, III, Beirut: Daar al Fikr

Al-Najjar, Z., Al-'Ijaz al-'Ilmi fi al-Sunnah al-Nabawiyah, terj. Zidni Ilham Faylasufa, Sains dalam Hadis, Amzah, Jakarta: 2011.

${ }^{52}$ M. K. De Genova, Intimate Relationships, Marriages \& Families (6th ed.), (New York: McGraw Hill, 2005), p. 79.

${ }^{3}$ Oluwole, \& Adebayo, D. "Marital Satisfaction: Connections of Self Disclosure, Sexual Self- Efficacy and Spirituality Among Nigerian Women”, Pakistan Journal of Social Sciences, vol. 5, no. 5 (2008), pp. 464469. 
Ayat Al-Quran, https://ayatalquran.net/2015/01/surah-an-nisaa-النساء-the-women-terjemahbahasa-inggris/, diakses pada tanggal 23 July 2019

Cahyadi Takariawan,, Izinkan Aku Meminangmu, Era Intermedia, Solo: 2004.

Clifford Geertz, Abangan, Santri, Priyayi dalam Masyarakat Jawa, PT. Midas Surya Grafindo, Jakarta: 1989.

D. Elfida,, "Penyesuaian Perkawinan Ditinjau dari Beberapa Faktor Demografi", Jurnal $\begin{array}{llllllll}\text { Psikologi, vol. } \quad 7, \quad \text { no. } 2 & \text { (2011), } & \text { pp. } 190 & - & 214\end{array}$ [https://doi.org/10.20885/psikologika.vol18.iss2.art2]

Euis Nurlaelawati, For the Sake of Protecting Religion: Apostasy and its Judicial Impact on Muslim's Marital Life in Indonesia, Journal of Indonesian Islam, vol. 10, no. 1, 2016, pp. 89-112

F. O’Dea, Thomas, Sosiologi Agama. CV. Rajawali, Jakarta: 1990.

Gianluca P. Parolin, Interfaith Marriages and Muslim Communities in Scotland: A Hybrid Legal Solution?, Electronic Journal of Islamic and Middle Eastern Law (EJIMEL), vol. 3 , no. 17,2015 , pp. $83-96$

Halford, K., Marriage and Relationship Education, (New York, NY: Guilford Press, 2011)

Hazan, C., \& Shaver, P. R., "Romantic Love Conceptualized As An Attachment Process", Journal of Personality and Social Psychology, vol. 52, no. 3 (1987), pp. 511-524 [https://doi.org/10.4324/9781351153683-17]

Herawati, T., "Manajemen Sumberdaya Keluarga dan Ketahanan Keluarga Peserta Program Pemberdayaan Masyarakat di Pedesaan (Kasus di Kabupaten Bogor), Disertasi, (Institut Pertanian Bogor, Bogor, Indonesia, 2012), p. 244

K. Ahmad MS, A., Sistem Pernikahan di Sulawesi Selatan dan Sulawesi Barat, I, INDOBIS Publishing Anggota IKAPI, Makassar: 2006.

K. De Genova, M., Intimate Relationships, Marriages \& Families (6th ed.), McGraw Hill, New York: 2005.

K. Thalib, Perkawinan Menurut Islam, al-Ikhlas, Surabaya: 1993.

KBBI, https:kbbi.web.id/zonasi, accessed at 25 July 2019.

Kersh, J., Hedvat, T. T., Hauser-Cram, P., \& Warfleld, M. E., "The Contribution of Marital Quality to The Well-being of Parents of Children With Developmental Disabilities", Journal of Intellectual Disability Research, vol. 50, no. 12 (2006), pp. 883-893. [https://doi.org/10.1111/j.1365-2788.2006.00906.x]

Lukito, Ratno, "The Enigma of Legal Pluralism in Indonesian Islam: The Case of Interfaith Marriage", Journal of Islamic Law and Culture, vol. 10, no. 2, 2008, pp. 179-91 [http://dx.doi.org/10.1080/15288170802236457]

M. Ali, Muslim Diversity: Islam and Local Tradition in Java and Sulawesi, Indonesia," Indonesian Journal Islam Muslim Soc., vol. 1, no. 1 (2011), pp. 7-20 [http://dx.doi.org/10.18326/ijims.v1i1.1-35]

M. Keesing, Roger, Antropologi Budaya, Penerbit Erlangga, Jakarta: 1981. 
M. Novenanty, W., Antara Pekerja Dalam Satu Perusahaan, Vol. 2, no. 1 (2015), pp. 60-85 [https://doi.org/10.25123/vej.2066]

Marhumah, Membina Keluarga Mawaddah Warahmah dalam Bingkai Sunnah Nabi, PSW IAIN Sunan Kalijaga, Yogyakarta: 2003.

Marriages, E., Marriage Quality and Family Well-Being Determine Parental Environment of, Journal of Marriage and Family, vol. 10, no. 1 (2017), pp. 1-12 [https://doi.org/10.1111/jomf.12422]

Minichele Sewenet, Alex, Fasil Merawi Tessagaye, and Getnet Tadele, "Interreligious Marriage: Social and Religious Perspectives", Imperial Journal of Interdisciplinary Research, vol. 3, no. 6 (2017), pp. 233-250 [https://doi.org/10.9783/9780812295115010]

Muchtar, K., Asas-asas Hukum Islam Tentang Perkawinan, Bulan Bintang, Jakarta: 1974.

Mulyati, S., Relasi Suami Istri dalam Islam, PSW UIN Syarif Hidayatullah, Jakarta: 2004.

Mustari, A., Reinterpretasi Konsep-konsep Hukum Pernikahan Islam, I, Alauddin University Press, Samata: 2011

N. L, Collins, \& Read, S. J., Adult Attachment, Working Models, and Relationship Quality in Dating Couples, Journal of Personality and Social Psychology, vol. 58, no. 4 (1990), pp. 644-663

Niswati, I.,Hubungan Loving, Kepuasan Seksual, dan Religiusitas dengan Keharmonisan Perkawinan, Jurnal Psibernetika, vol. 4, no. 2 (2011), pp. 1-32.

Nurviani, R., and R. Ilham, Efektivitas Pelatihan Empati dalam Mengurangi Konflik Perkawinan pada Pasangan Suami Istri yang Berada pada Tahun Awal Pernikahan, vol. 3, no. 2 (2018), pp. 165-176. [https://doi.org/10.21580/pjpp.v3i2.2954]

Oluwole \& Adebayo, D. Marital Satisfaction: Connections of Self Disclosure, Sexual SelfEfficacy and Spirituality Among Nigerian Women, Pakistan Journal of Social Sciences, vol. 5, no. 5 (2008), pp. 464-469.

Puspitawati, H., \& Setioningsih, S. S., Fungsi Pengasuhan dan Interaksi Dalam Keluarga Terhadap Kualitas Perkawinan dan Kondisi Anak Pada Keluarga Tenaga Kerja Wanita (TKW), Jurnal Ilmu Keluarga dan Konsumen, vol. 4, no. 1 (2011), pp. 11-20

Quraish Shihab, M., Pengantin al-Qur'an, (Tangerang: Lentera Hati, 2007)

R. Banse, Adult Attachment and Marital Satisfaction: Evidence Dyadic Configurations Effects, Journal of Social and Personal Relationships, Vol. 21, no. 2 (2004), pp. 273282

R. Ghozali, A., Fiqh Munakahat, (Jakarta: Pustaka Firdaus, 2008)

R. Hakim, Hukum Perkawinan Islam, (Bandung: Pustaka Setia, 2000)

R. Miller, \& Perlman, D., Intimate Relationship (5th ed.), (New York: McGraw-Hill, 2009)

Retno Prabowo, Mia, Penyesuaian Perkawinan Pada Pasangan Yang Berlatar Belakang Etnis Batak Dan Etnis Jawa, Skripsi Universitas Gunadarma, Fakultas Psikologi, (Jakarta, 2010) 
Rizkillah R., Sunarti, E., Herawati T., Kualitas Perkawinan dan Lingkungan Pengasuhan Pada Keluarga Dengan Suami Istri Bekerja, Jurnal Ilmu Keluaga dan Konsumen, vol. 8, no. 1 (2015), pp. 10-19

S. Hollist, C., \& Miller, R. B., Perceptions of Attachment Style And Marital Quality in Midlife Marriage. Family Relations, vol. 54, no. 1 (2005), pp. 46-57 [https://doi.org/10.1111/j.0197-6664.2005.00005.x]

S. Lai, C., "Parental Marital Quality and Family Environment as Predictor of Delinquency Amongs Selected Secondary School Students in Malaysia", British Journal of Arts and Social Sciences, vol. 2, no. 2 (2011), pp. 102-121 [https://doi.org/10.14689/ejer.2018.78.5]

Sahrani, Sohari, Fikih Munakahat Kajian Fikih Nikah Lengkap, (Serang: PT Raja Grafindo Persada, 2008)

Septiani Manik, Helga, "Makna dan Fungsi Tradisi Sinamot dalam Adat Perkawinan Sukubangsa Batak Toba di Perantauan Surabaya”, vol. I, no. I (2012), pp. 19-32

Sewenet, Alex Minichele, Fasil Merawi Tessagaye, and Getnet Tadele, "Interreligious Marriage: Social and Religious Perspectives, Imperial Journal of Interdisciplinary Research, vol. 3, no. 6 (2017), pp. 122-134

Siddiqui, Mona, Menyikap Tabir Perempuan Islam, Nuansa, Bandung: 2007.

Syahraeni, A., Bimbingan Keluarga Sakinah, Alauddin Press, Makasar: 2013.

Syarifuddin, A., Hukum Perkawinan Islam di Indonesia, Antara Fiqh Munakahat dan Undang-Undang Perkawinan, III, Kencana, Jakarta: 2009.

T. D. Raphalalani and N. M. Musehane. Arranged Marriage Practices of the Vhavenda Community of the Vhembe District, Journal of Limpopo Province, South Africa, vol. 4 no. 2 (2013), pp. 18-22. 